\title{
Marco introdutório
}

A histórica Conferência Internacional sobre Cuidados Primários de Saúde promovida pela Organização Mundial da Saúde (OMS) em Alma-Ata completou 30 anos em 2008. Não obstante os esforços desenvolvidos, o mundo ainda está longe de alcançar a meta "Saúde Para Todos no Ano 2000", proclamada com entusiasmo, naquela ocasião, pelas delegaçóes de 134 países e por dezenas de representantes de organismos internacionais com interesse na área da saúde.

Decorridos tantos anos, "ainda é lamentável a situação de saúde de grande parcela da humanidade, pois a mesma ainda não goza de uma atenção à saúde integral, equitativa ou nem sequer básica" (Declaração de Buenos Aires: de Alma-Ata à Declaração do Milênio, 2007).

Mas já pode ser considerado um grande avanço constatar que, 30 anos depois, falar sobre Atenção Primária à Saúde (APS) não provoca mais questionamentos sobre a sua importância para a estruturação dos sistemas de saúde. A inteligência sanitária mundial tem evidenciado o acerto da estratégia consagrada em Alma-Ata. Hoje em dia, é consenso entre os formuladores de políticas de saúde que os Cuidados Primários de Saúde constituem a chave mestra para que a "Saúde Para Todos" possa ser transformada em realidade.

Seja no âmbito dos serviços e das instâncias de gestão ou no meio acadêmico, é sabido que, sem um sistema de saúde com base na APS, não é possível constituir políticas de saúde equitativas, eficientes e efetivas. Ao contrário, sabe-se que, sem uma APS qualificada, os sistemas de saúde tornam-se progressivamente mais fragmentados, iatrogênicos e, ainda, acumulam custos elevados e desnecessários.

Mas é preciso reconhecer: ainda há grandes distâncias entre as intençôes e as decisōes e açôes.

Muitos obstáculos à implantação da APS ainda existem. Obstáculos de origens e ordens diversas, incluindo a lógica de mercado, fruto dos interesses do complexo médico-industrial e sua influência na configuração dos sistemas de saúde. Dificuldades operacionais ou conceituais são encontradas em algumas regiôes, em instituiçôes de ensino e em relação às iniciativas governamentais: alguns deles, implementando açóes efetivamente transformadoras; outros, denotando considerável perplexidade, acionam e investem em programas que mais contribuem para perpetuar as condiçóes existentes, do que para caminhar em direção às mudanças necessárias.

Apesar disto, a efetividade e a resolutividade da APS têm sido cada vez mais evidenciadas. Estudos comparativos vêm dissipando dúvidas eventualmente remanescentes: países que conseguem instituir sistemas de saúde organizados com base em um modelo qualificado e inclusivo de APS vêm obtendo resultados incontestes, seja em relação à cobertura assistencial seja em relação aos custos, com melhores indicadores de saúde.

Neste contexto, cabe promover uma reflexão sobre a relevância da Medicina de Família e Comunidade, enquanto especialidade médica mais adequada para atuar neste campo da atenção.

A Atenção Primária à Saúde sem a efetiva participação da Medicina de Família não deve mais ser considerada completa e vice-versa.

Esta compreensão foi sendo progressivamente construída no próprio rastro de Alma-Ata. Isto porque, desde então, se avançou muito no tocante à necessidade de uma qualificação profissional coerente com a APS e, simultaneamente, com a ampliação do conceito de saúde e adoecimento e seu impacto no âmbito do saber e da prática médica. 
$\mathrm{Na}$ década de 70, começavam a se evidenciar, de forma mais visível, os limites do modelo anatomoclínico, pilar do paradigma biomédico, que projetou a doença - tida como entidade - como objeto e foco principal da atenção médica.

Com base neste paradigma, ainda vigente, o valor e a importância do profissional e das suas práticas são tão maiores quanto mais focais e pontuais forem o seu olhar e sua intervenção sobre as disfunçóes fisiológicas, sobre as doenças. A atuaçáo dentro dos hospitais ainda é fortemente compreendida como mais "complexa" visto que, naquele espaço, se lida com "doenças complexas" e se utilizam instrumentos industrializados "de alta complexidade".

Formação, saber e prática médica, status e valoração profissional são ainda, em grande parte, afeitos a tal concepção biotecnicista.

Assim sendo, com base neste mesmo paradigma, os profissionais que se voltam e desenvolvem açóes na e para a APS, não necessitariam desenvolver qualificação específica para aplicar as tecnologias próprias deste campo de práticas, o que remete a uma visão simplista e desqualificada do que seja a complexidade do trabalho neste nível de atenção.

Esta compreensão equivocada pode, em parte, servir de explicação para a eventual carência de incentivos e políticas específicas que ainda é possível observar em muitas regiōes.

Nestas ultimas décadas, entretanto, a ciência tem demonstrado que o processo saúde-doença é um fenômeno complexo, no qual atuam variáveis de diferentes dimensóes, biológica, psicológica, cultural e social. Além disso, o perfil de morbidade e mortalidade das populaçóes, a expectativa de vida, a sociedade e a cultura constituem uma realidade bastante diversa daquela configurada por ocasião da emergência e do estabelecimento da medicina anatomoclínica.

Se, àquela época, as doenças infecciosas representavam o grande desafio, hoje são as doenças crônicodegenerativas, influenciadas pelos hábitos e estilos de vida, adquiridos na família e na sociedade que o representam. São os adoecimentos gerados pela violência, pelas condiçôes gerais de vida, nas grandes e pequenas cidades, pelos valores impostos pela sociedade de consumo e pela globalização. Ampliaram-se os fatores e as situaçóes de risco.

Não se pode mais relegar a um segundo plano as ações de promoção e educação em saúde. Nem se pode mais aguardar que os processos de adoecimento prossigam em sua "evolução natural", para serem então objeto de "recuperação" pela medicina.

Impóe-se o desenvolvimento de açóes de promoção à saúde, bem como trabalhar mecanismos de resiliência, buscando as medidas que visem ambientes e práticas sociais saudáveis. Identificar precocemente como e por que as pessoas adoecem e contribuir para reassumirem o caminho da saúde constitui o elemento central pelo qual devem se organizar e atuar os sistemas de saúde.

Por isto tudo, compreende-se hoje, com maior clareza, a importância da Atenção Primária à Saúde. É neste nível de atenção em que tudo se inicia. Aqui devem ser desenvolvidas - de forma integrada e articulada - ações de educação, promoção, prevenção, recuperação e reabilitação para os problemas mais prevalentes de saúde. $\mathrm{O}$ foco não são as partes do corpo ou os sistemas orgânicos, mas sim as pessoas, as famílias, a comunidade e seus processos de adoecer e preservar a saúde.

As questôes a serem abordadas e desenvolvidas na APS são, portanto, complexas, e os profissionais devem ter formação específica e adequada para lidar com as necessidades e demandas de saúde que aí se apresentam, trabalhando na perspectiva do cuidado e da autonomia.

De Alma-Ata para cá, muito já se caminhou e se tem caminhado neste sentido, tanto em relação à compreensão e implementação da APS quanto em relação à qualificação dos seus profissionais, em especial do Médico de Família e Comunidade. Muitas e boas liçôes podem ser extraídas da experiência de países com diferentes níveis de desenvolvimento econômico, inclusive da Ibero-América, a exemplo de Cuba, Brasil, México, Costa Rica, Espanha e Portugal.

Mas ainda há grandes distâncias entre intenção e gesto, especialmente nos paises ditos em desenvolvimento. $\mathrm{Na}$ região da Ibero-América, dentre os principais desafios se encontram: 
a) Conformar e organizar sistemas nacionais de saúde mais justos e equânimes, e que tenham por base a APS e a atuação de Médicos de Família.

b) Promover políticas de saúde que garantam minimamente o acesso de toda a população à Medicina de Família e Comunidade e à Atenção Primária à Saúde (como direito de todos e dever do Estado).

Para tanto, é necessário que se estabeleçam, se implementem e se incrementem políticas para fortalecer a:

1) valorização e valoração da MFC e da APS nos sistemas de saúde com constituição de mercado e condiçôes adequadas de trabalho;

2) formação e capacitação de médicos de família e comunidade;

3) formação e capacitação de educadores, tutores e docentes em Medicina de Família e Comunidade;

4) institucionalização acadêmica da Medicina de Família e Comunidade;

5) produção e divulgação de conhecimento no âmbito da Atenção Primária à Saúde e da Medicina de Família.

Todas estas questóes têm sido objeto de estudo na esfera da Confederação Ibero-Americana de Medicina Familiar (CIMF) e têm sido trabalhadas nas Cúpulas e demais atividades da CIMF e de suas regionais nacionais.

A I Cúpula, realizada na Espanha (2002), a II Cúpula, realizada no Chile (2005), assim como a I Minicúpula, realizada na Venezuela (2003), apresentaram recomendaçóes e açóes concretas para enfrentar e superar os desafios para a Medicina Familiar e a Atenção Primária à Saúde no nível da Ibero-América.

Com base nestas recomendaçôes e numa enquete realizada com os países membros da Confederação IberoAmericana de Medicina Familiar - CIMF sobre o atual estágio de desenvolvimento dos sistemas de saúde, da MF e APS na Ibero-América, configuraram-se os objetivos propostos para a III Cúpula.

O presente informe resume o desenvolvimento, as propostas e os principais acordos da III Cúpula IberoAmericana de medicina familiar expressos na carta de Fortaleza que vai ao final desde documento. 